\author{
https://doi.org/10.52449/1857-4114.2020.35-1.07
}

CZU: 378.1:796.5+159.923.2

\title{
VOCATIONAL TRAINING OF FUTURE SPECIALISTS IN THE FIELD OF TOURISM BASED ON PERSONALITY QUALITIES
}

\author{
Lungu Ecaterina ${ }^{1}$, ORCID: 0000-0001-9262-2816 \\ Calugher Viorica ${ }^{2}$, ORCID: 0000-0003-0405-5917 \\ Braniște Gheorghe ${ }^{3}$, ORCID: 0000-0003-1995-2442 \\ ${ }^{1,2,3}$ State University of Physical Education and Sport, Chișinău, Republic of Moldova
}

\begin{abstract}
The current training system for specialists in the field of tourism is oriented towards the continuous change of society and tends to continuously increase the quality of provided services. One of the peculiarities of the specialties in the field of tourism is the impossibility to work within the limits of a narrow specialization, of major importance being the personality characteristics, which ensure maximum efficiency and success in the profession. The aim of the research is the study of the personality and professional qualities necessary for the future specialist in the field of tourism. The research methods applied in the study were: the method of scientific documentation, the questionnaire, the statistical-mathematical method. The main results of the research showed that students appreciate the most for the future profession the higher education in tourism, knowledge of technologies for organizing the tourism industry and the basics of psychology, which reflects the content of the vocational training process at the university. At the same time, the experience in the field is placed on the last positions, which reflects the low number of practical activities (performed only during the internship). Thus, students studying at the specialized faculty are aware of the importance and need for personal and professional qualities for the future professional activity and appreciate the importance of specialized knowledge and professional skills in becoming highly qualified specialists.
\end{abstract}

Keywords: personality qualities, professional skills, career.

Actuality. The intensive development of the field of tourism has contributed to the initiation of university study programs in the specialty of tourism. One of the conditions for successful development in any field is highly qualified human resources. The tourist potential of the Republic of Moldova attracts more and more tourists in recent decades, thus it has become necessary to train highly qualified specialists in the field of tourism by ensuring a high quality education [1].

The current training system for specialists in the field of tourism is oriented towards the continuous change of society and the tendency to continuously increase the quality of services provided. One of the peculiarities of the specialties in the field of tourism is the impossibility to work within the limits of a narrow specialization.

In the field of tourism there is the phenomenon of the "carousel of professions", which means that the specifics of professional activity in tourism require the ability to make the transfer from one sphere to another and rapid adaptation to social change.

This requires the tourism education system to take into account global experience in the field, to change traditional training methods and to adapt modern technologies so that future tourism specialists are trained in general and specific skills [2]. A strategic objective is to create the conditions for the formation and 
development of an open and energetic personality, diplomatic and creative, communicative and easy to integrate into various social groups.

The important professional qualities for the future specialist in the field of tourism are the personality characteristics, which ensure maximum efficiency and success in the profession. The analysis of the literature highlights the personality qualities that are manifested in professional activity [3] and which are classified into the following groups (Figure 1):
- moral-volitional - esteem for people, humanism, tact, civic activism, tolerance, justice, emotional and behavioral balance, dynamism, energy, ambition, insistence, determination, self-confidence, organization, discipline, courage, etc.

- intellectual - professional competence, erudition, analytical spirit, flexibility, reasoning, ability to learn, etc.

- communication - sociability, ability to listen, ability to persuade, sense of humor, etc.

- organizational-managerial - activism, creativity, initiative, responsibility, objectivity, work capacity, independence, etc.

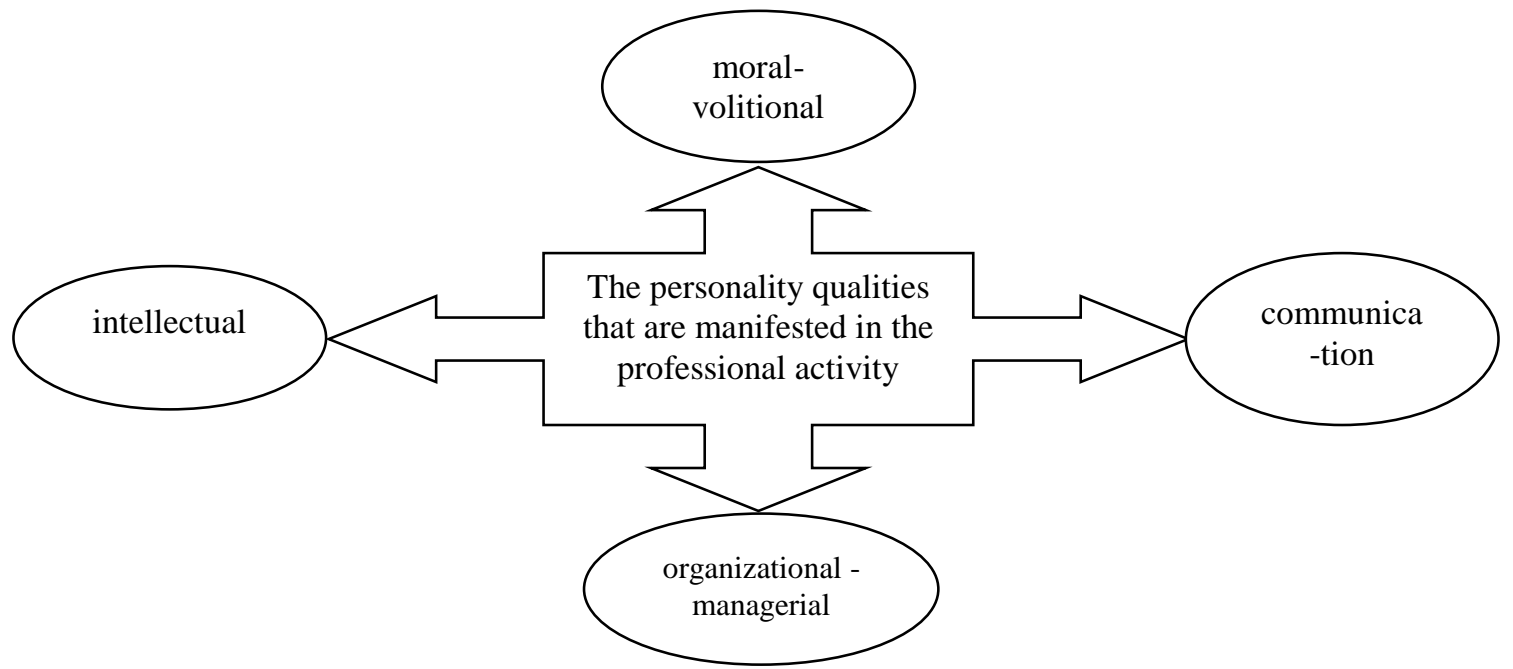

Fig. 1. The personality qualities that are manifested in the professional activity (according to $O . A$. Брель, М.И. Губанова, 2013 [5, р. 18-21])

The analysis of the specialized literature and the results of the students survey from the tourism specialties allowed to highlight the personality and professional qualities of the specialist in the field of tourism.

Based on the existing professional programs, professional characteristics and competencies, the students were presented with a list of 20 personality qualities and 20 professional qualities, from which they had to choose the most important 8-10 for the future specialist in the field of tourism by grading from 1 to 10.

The students mentioned as the most important the following personality qualities: self-confidence,

communicativeness, emotional balance, responsibility, pleasant appearance, kindness, initiative and erudition.

Among the professional qualities, students mentioned as more important: higher education in tourism, knowledge of geography, knowledge of organizing technologies in the tourism industry, possession of ICT tools, knowledge of foreign languages, knowledge of tourism legislation, knowledge of the psychology basics, ability to work with documentation and work experience in the field of tourism industry. 
The grading of the qualities necessary for reflected in Table 1. the future tourism specialist by students is

Table 1. Rating of the importance of personality and professional qualities of tourism specialists by students

\begin{tabular}{|r|l|c|}
\hline \multicolumn{1}{|c|}{ Rank } & \multicolumn{1}{|c|}{ Personality Qualities } & Average marks \\
\hline \multicolumn{2}{|c|}{ Pam qualities } & $\mathbf{7 , 8}$ \\
\hline $\mathbf{1 .}$ & Communicativeness & $\mathbf{7 , 7}$ \\
\hline $\mathbf{2 .}$ & Stress resistance & $\mathbf{7 , 0}$ \\
\hline $\mathbf{3 .}$ & Responsibility & $\mathbf{6 , 8}$ \\
\hline $\mathbf{4}$. & Self-confidence & $\mathbf{6 , 7}$ \\
\hline $\mathbf{5 .}$ & Pleasant appearance & $\mathbf{6 , 3}$ \\
\hline $\mathbf{6 .}$ & Kindness & $\mathbf{6 , 0}$ \\
\hline $\mathbf{7 .}$ & Initiative & $\mathbf{5 , 8}$ \\
\hline $\mathbf{8 .}$ & Scholarship & $\mathbf{8 , 1}$ \\
\hline & \multicolumn{1}{|c|}{$\mathbf{8 , 0}$} \\
\hline $\mathbf{1 - 2}$ & Higher education in tourism & $\mathbf{7 , 8}$ \\
\hline $\mathbf{1 - 2}$ & $\begin{array}{l}\text { Knowledge of technologies organization of the tourism } \\
\text { industry }\end{array}$ & $\mathbf{7 , 6}$ \\
\hline $\mathbf{3}$ & Knowledge of geography & $\mathbf{7 , 3}$ \\
\hline $\mathbf{4}$ & Possession of ICT tools & $\mathbf{7 , 1}$ \\
\hline $\mathbf{5}$ & Possession of foreign languages & $\mathbf{6 , 8}$ \\
\hline $\mathbf{6}$ & Knowledge of the legislative basis in the field of tourism & $\mathbf{6 , 5}$ \\
\hline $\mathbf{7}$ & Knowledge of the psychology basics & $\mathbf{6 , 0}$ \\
\hline $\mathbf{8}$ & Ability to work with documentation & \\
\hline $\mathbf{9}$ & Work experience in the tourism industry &
\end{tabular}

Among the personality qualities on the first 3 positions are mentioned communication, resistance to stress and responsibility, on the latter one - initiative and scholarship. At the same time, we mention that the grades for personality qualities do not differ much from the first to the last position (7,8 the highest grade and 5,8 - the quality from the last position). Thus, we can conclude that students highly appreciate all the personality qualities in the activity of the specialist in the field of tourism.

The data obtained when noting the professional qualities demonstrate the equal importance of the first 2 qualities - higher education in the field of tourism and knowledge of the technologies for organizing the tourism industry. No less important, with small differences in appreciation, students consider knowledge of geography. The middle positions were obtained by the qualities related to communication in foreign languages, technical and managerial skills. The ability to work with documentation and experience in the field were placed on the last positions, the students considering that they can be acquired during the professional activity.

At the same time, the students were asked to assess themselves according to the proposed personality and professional qualities. The results obtained are reflected in Figure 1 and Figure 2.

Most students consider themselves responsible $(7,0)$, the criterion related to the 
pleasant appearance was marked with 6,7 ; initiative $-6,0$; self-confidence $-6,8$; on the first positions were placed stress resistance $(7,7)$ and communicativeness $(7,8)$.

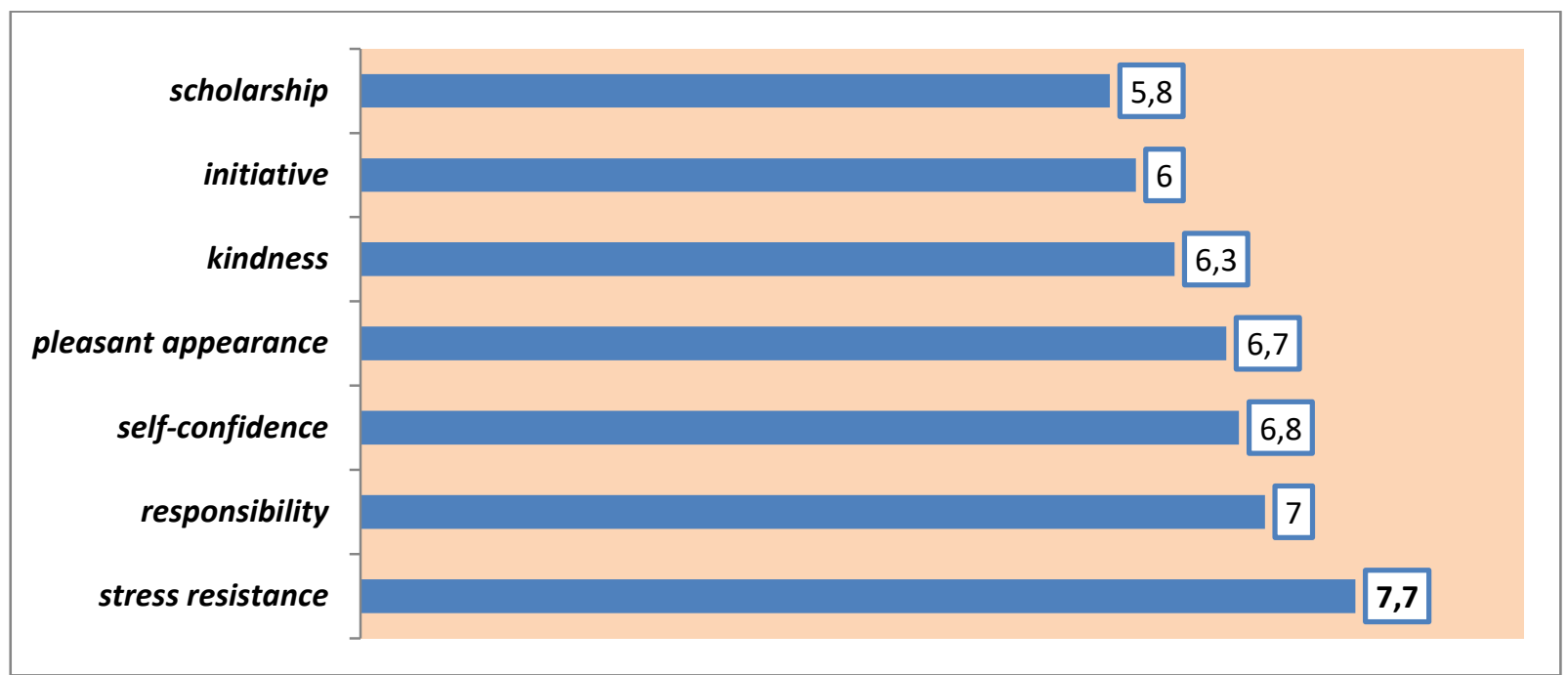

Fig.2. The results obtained following the self- assessment of personal qualities by students

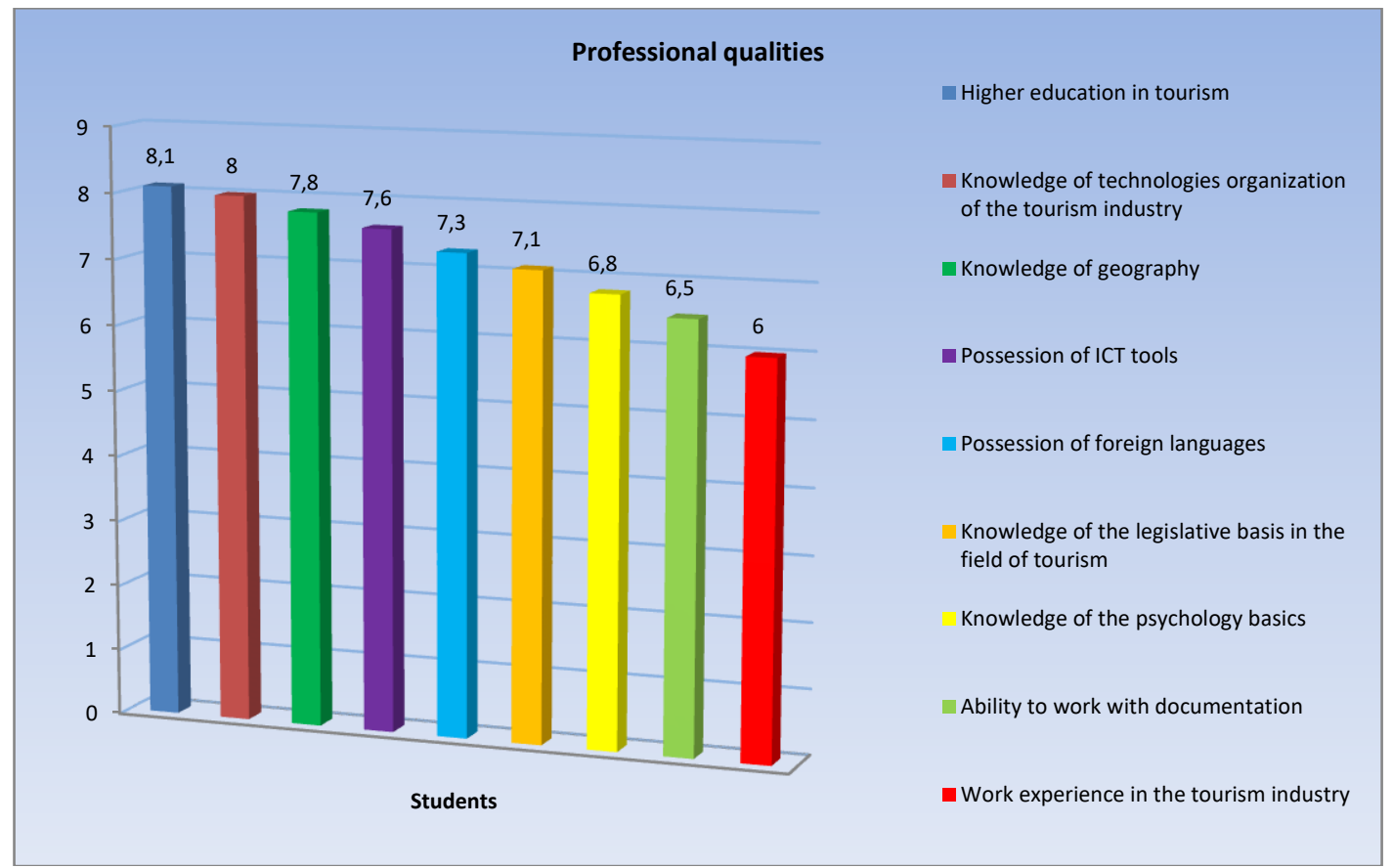

Fig.3. The results obtained following the self-assessment of professional qualities by students

The results of research have shown that students appreciate the most for their future profession the higher education in tourism, knowledge of technologies for organizing the tourism industry and the basics of psychology, which reflects the content of the vocational training process within the university. At the same time, the experience in the field is placed on the last positions, which reflects the low number of practical activities (performed only during the internship) [4].

Thus, students studying at the faculty are aware of the importance and need for personal and professional qualities for future 
professional activity and appreciate the importance of specialized knowledge and professional skills in becoming highly qualified specialists.

\section{References:}

1. Mindrigan, V., Onoi, M., Demcenco, P. Pregătirea profesională a studenţilor specialitatea „Cultura fizică recreativă” în cadrul practicii de iniţiere. În: Sport, Olimpism, Sănătate: Materialele Congresului Ştiinţific Internaţional. Vol. I. Chişinău: USEFS, 2016, pp. 414-418.

2. Компетентностный подход в педагогическом образовании: коллективная монография. (2005). Под ред. проф. В.А. Козырева, проф. Н.Ф. Радионовой и проф. А.П. Тряпицыной. СПб. 392 с.

3. Войтенко М.В., Лаврентьева Н.Б., Редькин А.Г. (2010). Развитие творческого потенциала будущих специалистов по туризму на основе технологии учебного проектирования. Барнаул. 199 с.

4. Квартальнов В.А. (2000). Педагогика и туризм: учебное пособие. Москва: .

5. Брель О.А., Губанова М.И. (2012). Личностно ориентированная профессиональная подготовка будущиих специалистов сферы туризма. В: Педагогика и психология, № 22(74), c. $18-21$. 